\title{
Workshop Reports
}

\section{Nutrition information and training: networking in international community nutrition}

\author{
BY JACQUELINE LANDMAN \\ Department of Human Nutrition, University of Southampton, Southampton SO9 $3 T U$
}

AND ANN BURGESS

Craiglea Cottage, Blairgowrie PH11 8PS

Twenty-two participants with varied international backgrounds attended the first satellite meeting organized by Ann Burgess, under the auspices of the Task Force on Overseas Members (TFOM). The meeting aimed to find ways to provide information and support to overseas members, particularly those in low-income countries. There were three short presentations followed by round-table discussion of the target audience's need for information about: nutrition and related training courses, in and outside the UK; sources of funding for training, research, subscriptions and travel to meetings; new relevant low-cost publications; abstracts of key papers in international nutrition and employment overseas.

The first speaker, Professor Andrew Tomkins, from the Centre for International Child Health, Institute of Child Health, London University, outlined two new projects: first, the networking project whereby Teaching Aids at Low Cost (TALC) is revising its training materials. Individuals who contribute one good slide will receive the whole set; second, the Wellcome Trust Tropical Disease Videodisc Project, which will produce a comprehensive archive and learning resource.

The second speaker was Dr Leslie Burgess, former Secretary of the United Nations (UN) Advisory Committee on Coordination's Subcommittee on Nutrition. The UN ACC/SCN links the nutrition work of seventeen UN agencies, several major nongovernmental and bilateral aid agencies, producing state-of-the-art scientific reviews and a newsletter ( $S C N N e w s$ ), to inform policy and influence the World Bank, United Nations Children's Fund and other aid agencies. Free access to both newsletter and network would be valuable for advocacy by national nutritionists.

Dr Rakesh Mittal, Visiting Research Fellow at Southampton, described ari Indian network of regional Nutrition Research and Training Centres, funded by his government to spread the geographical supply of scientific expertise relevant to the needs of the states they serve for manpower and technical information.

A lively round-table discussion led to agreement to create an active network, to be coordinated by Ann Burgess and Jackie Landman in the first instance, with members' help to ensure full participation. Communication is vital to networking, through existing newsletters. Leslie Burgess will explore help from ACC/SCN. Members of the network will help to prepare occasional fact sheets, which could be distributed with the Society's regular mailings: the first, Low Cost Recent Nutrition Publications has been prepared (Ann Burgess). The network plans to meet at the annual summer meetings of the Society. 